\title{
IGF-I Stimulates Tropoelastin Synthesis in Neonatal Rat Pulmonary Fibroblasts
}

\author{
AKIHIKO NOGUCHI AND TRACY NELSON \\ Pediatric Research Institute, Cardinal Glennon Children's Hospital, St. Louis University, School of Medicine, \\ St. Louis, Missouri 63104
}

\begin{abstract}
We have examined the effect of IGF-I on tropoelastin (TE) synthesis in cultured rat neonatal pulmonary fibroblasts, because this growth factor has been shown to stimulate TE synthesis in vascular smooth muscle cells. IGF-I stimulated TE and total protein synthesis in a dose-dependent manner even when cells were cultured in the medium supplemented with $0.5 \%$ FCS. The maximal stimulation was at IGF-I concentration $500 \mathrm{ng} / \mathrm{mL}$ and was an increase of $86 \pm 14$ and $35 \pm 5 \%$ for TE and estimated total protein synthesis, respectively. There was a corresponding $95 \pm 20 \%$ increase in the TE mRNA $/ \beta$-actin mRNA ratio assessed by densitometry of the Northern blot analysis. At this low concentration of FCS, however, there was neither TE stimulation by dexamethasone alone nor in combination with IGF-I. We conclude that IGF-I stimulation of TE synthesis may occur in cells other than vascular smooth muscle cells and that there is no additive stimulation by glucocorticoids. (Pediatr Res 30: 248-251, 1991)
\end{abstract}

\section{Abbreviations}

RPF, rat pulmonary fibroblasts

TE, tropoelastin

DEX, dexamethasone

An extracellular protein component, elastin, may play an important role in the formation of the terminal airsac/alveolus during perinatal lung morphogenesis in various animals and in humans (1-8)

The pro-form protein, TE, is a soluble protein of approximately 72000 to 75000 molecular weight $(9,10)$, and the regulation of synthesis is poorly understood, partly because regulatory elements of the gene have not been fully defined (11). We have previously demonstrated that cultured RPF are elastogenic in early passaged cells and that TE expression is stimulated by DEX (12). To further understand the humoral factors that could stimulate TE synthesis in the developing lung, we have examined IGF-I in the present study. IGF-I has been shown to stimulate TE expression in vascular smooth muscle tissue and cells $(13,14)$, but this effect on other cell types including RPF has not been reported. We found that IGF-I stimulates TE synthesis in the neonatal RPF in a dose-dependent manner.

\section{MATERIALS AND METHODS}

Cell culture. Postnatal rats at $7 \mathrm{~d}$ were killed with an intraperitoneal injection of Nembutal $(50 \mathrm{mg} / \mathrm{kg}$; Eli Lilly Co., Indian-

Received September 24, 1990; accepted May 10, 1991.

Correspondence: Akihiko Noguchi, M.D., Department of Pediatrics, St. Louis University, School of Medicine, 1465 South Grand, St. Louis, MO 63104

Supported in part by grants from the March of Dimes (no. 1-1121) and American Lung Association of Eastern Missouri. apolis, IN). The project was approved by the Animal Care Committee of St. Louis University. Postnatal d 1 was counted as the birth date, and RPF were isolated as described before (12). Selection of the ages and response to DEX stimulation was dependent on our previous finding that TE expression is maximum at $7 \mathrm{~d}(12)$. Pups from two or three litters were combined and were used for extraction of total RNA and isolation of pulmonary fibroblasts by the differential adhesion method (15). The cells were passaged once and maintained in RPMI 1640 supplemented with $10 \%$ FCS until just before confluency and then in RPMI 1640 with $0.5 \%$ FCS to minimize the IGF-I effects of the FCS (14). At this FCS concentration, the results were more consistent than with $0.1 \%$ FCS. Twelve $\mathrm{h}$ after the medium switch, cells were treated with increasing concentrations of IGFI for another $48 \mathrm{~h}$, harvested by $0.25 \%$ trypsin and $0.01 \%$ EDTA treatment, and processed for extraction of total RNA (12). Cell counts were determined simultaneously using a hematocytometer. TE concentrations in conditioned media were determined by an ELISA.

Electron microscopy. A separate set of RPF at the first passage were grown in a Thermanox plastic dish (ICN Biomedical Inc., Costa Mesa, CA) in RPMI 1640 supplemented with $10 \%$ FCS. At $10 \mathrm{~d}$ (preconfluent) the RPF were fixed with $2 \%$ glutaraldehyde for $2 \mathrm{~h}$ at $24^{\circ} \mathrm{C}$ and embedded in Spurr's resin (Polysciences, Warrington, PA) and thin sections were examined with a model 100 S electron microscope (JEOL USA, Peabody, MA).

Immunofluorescent staining. A fraction of RPF was passaged onto sterile microscopic slides and grown to preconfluency, and the cells were fixed with methanol at $-20^{\circ} \mathrm{C}$ for $5 \mathrm{~min}$ and reacted with antibodies for vimentin, smooth muscle specific

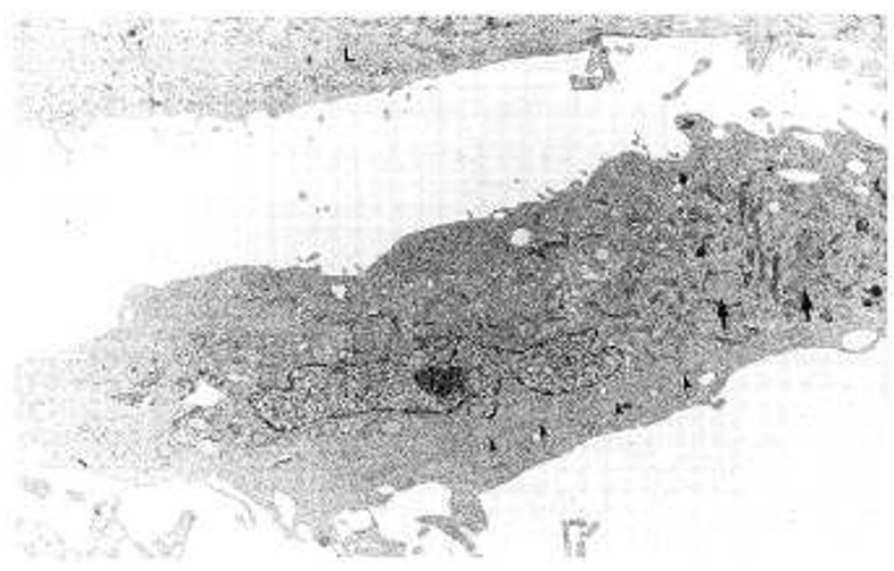

Fig. 1. Representative transmission electron micrograph of a pulmonary fibroblast. The cells at the first passage were maintained for 10 d. Prominent cisternae of rough endoplasmic reticulum (arrows), a small amount of microfilamentous bundles (arrowheads), and the lack of an incomplete basal lamina outside the plasma membrane are characteristics of these cells. The cells often have lipid vacuoles $(L)$ of different sizes, as seen in the upper cell. Magnification $\times 7800$. 

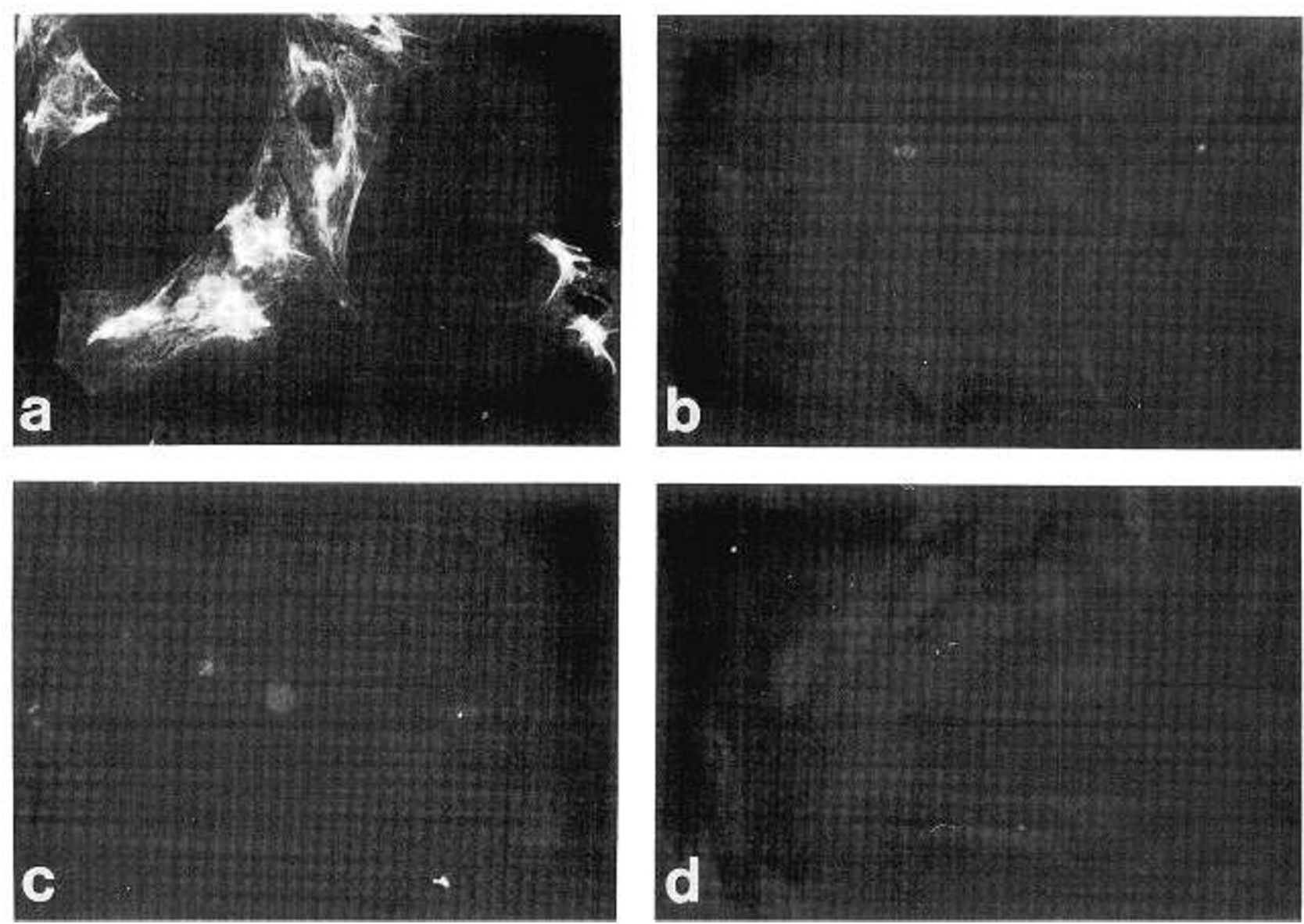

Fig. 2. Immunofluorescence for cytoskeletal proteins. Seven-d RPF were passaged once and fixed in methanol as described in Materials and Methods. The cells were positive for vimentin only. $a$, Vimentin; $b$, smooth muscle actin; $c$, smooth muscle myosin; $d$, desmin. Magnification $\times 400$.

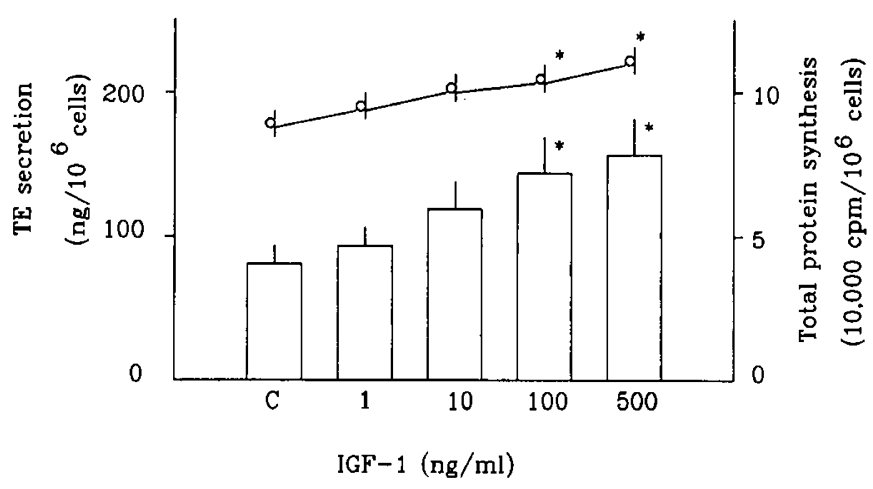

Fig. 3. Dose response of TE (bar graph) and ${ }^{3} \mathrm{H}$-leucine incorporation into proteins (line graph) synthesis to increasing IGF-I concentrations. Secreted TE values were determined using the conditioned media, and protein synthesis values were determined using the media and cell extract combined sample as in Materials and Methods. Mean \pm SEM of six different sample determinations. ${ }^{*}, p<0.05$.

actin, smooth muscle/skeletal muscle myosin, and desmin. The slides were then reacted with a fluorescein-conjugated second antibody and examined under a fluorescent microscope.

Total protein synthesis. Protein synthesis was estimated by determining ${ }^{3} \mathrm{H}$-leucine incorporation into newly synthesized protein as described before (12) with minor modifications. The medium ( $5 \mathrm{~mL} /$ dish) and cell layer grown in a separate dish was washed three times with PBS, and media was switched to leucinedeficient RPMI supplemented with $0.5 \%$ FCS. RPF were treated with various concentrations of IGF-I for the last $48 \mathrm{~h}$. At $12 \mathrm{~h}$ treatment time, $5 \mu \mathrm{L}$ of ${ }^{3} \mathrm{H}$-leucine $(60 \mathrm{Ci} / \mathrm{mmol}, 1 \mathrm{mCi} / \mathrm{mL})$ was added to the medium. Then the cell layer was scraped with

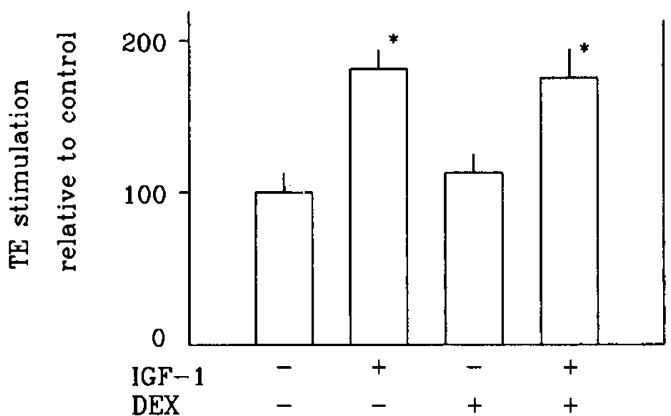

Fig. 4. TE stimulation examined in the presence of IGF-I $(500 \mathrm{ng} /$ $\mathrm{mL})$ and/or DEX $\left(10^{-7} \mathrm{M}\right)$. Values were expressed as the percentage of increase from the control $(100 \%)$. Mean \pm SEM of six different sample determinations. ${ }^{*}, p<0.01$.

a rubber policeman, and medium and cell layer together were collected in a tube and homogenized with a Tekmar (Cincinnati, $\mathrm{OH})$ homogenizer for $10 \mathrm{~s}$ at $4^{\circ} \mathrm{C}$. Aliquots of $100 \mu \mathrm{L}$ were solubilized immediately in $0.1 \mathrm{~N} \mathrm{NaOH}$, neutralized in $0.1 \mathrm{~N}$ $\mathrm{HCl}$, and precipitated with $200 \mu \mathrm{L}$ of ice-cold $20 \%$ trichloroacetic acid, and the pellet was collected by centrifugation. After washing with ice-cold $10 \%$ trichloroacetic acid once, the pellet was dissolved in $100 \mu \mathrm{L}$ of $1 \mathrm{M} \mathrm{NaOH}$ overnight at room temperature and counted in a Hewlett-Packard scintillation counter.

ELISA. TE concentration was determined by the method of ELISA as described before (12) using chicken anti-rat elastin antibody (1:2000), and rat $\alpha$-elastin (40 ng/100 $\mu \mathrm{L} /$ well) was purified from rat aorta by the method of Partridge et al. (16) as the standard. TE content was calculated from the standard curve of the colorimetric reading using Minireader 2 (Dynatech, 

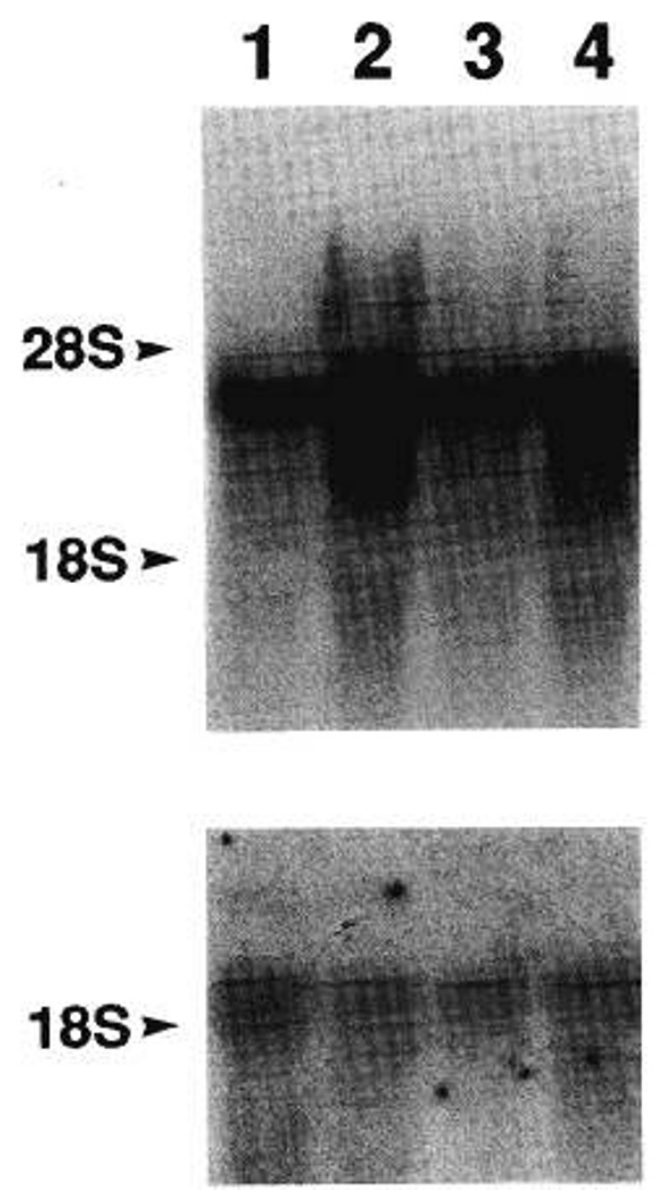

Fig. 5. Representative Northern blot analysis showing TE mRNA (upper panel) and $\beta$-actin mRNA (lower panel) in response to IGF-I (500 $\mathrm{ng} / \mathrm{mL})$ and/or DEX $\left(10^{-7} \mathrm{M}\right)$. Lane 1, untreated control; lane 2, IGF-I alone; lane 3, DEX alone; lane 4, IGF-I plus DEX.

Alexandria, VA). The background in unconditioned medium containing $0.5 \%$ FCS was subtracted from each value.

Northern blot analysis. The procedure was used as described before, except the amount of $20 \mu \mathrm{g}$ per lane was fractionated by $1 \%$ agarose gel containing $6 \%$ formaldehyde. Hybridization was performed with nick-translated rat elastin cDNA ${ }^{32} \mathrm{P}-\mathrm{RE} 2$ at $42^{\circ} \mathrm{C}$ in a buffer containing $50 \%$ formamide, $10 \times$ sodium chloride sodium citrate buffer, $100 \mathrm{mM} \mathrm{Na}$ phosphate, $\mathrm{pH} 6.5,10 \times$ Denhardt's solution (17), and $1 \mathrm{mg} / \mathrm{mL}$ salmon sperm DNA. Washing conditions were as described before (12). The dried filter was exposed to Kodak XAR film at $-70^{\circ} \mathrm{C}$. Later, the same filter was hybridized with nick-translated chicken ${ }^{32} \mathrm{P}$ - $\beta$-actin cDNA (18) in pGEM $4 Z$ and processed. $\beta$-Actin probe was used as the control probe to make a comparison with the TE mRNA. Densitometric analysis of the autoradiographs was performed using a model no. 620 video densitometer (Bio-Rad Laboratories, Anaheim, CA).

Materials. Chicken anti-rat $\alpha$-elastin serum and RE2 cDNA were provided by Judith Foster, Ph.D. (Boston University) and used as described before (12). Recombinant human IGF-I was purchased from AmGen Biologicals (Oak Park, CA), and ${ }^{32} \mathrm{P}$. nucleotide and ${ }^{3} \mathrm{H}$-leucine were purchased from New England Nuclear (Boston, MA). Antibodies for vimentin, smooth muscle/ skeletal muscle myosin, desmin, and fluorescein-conjugated antibody were from Sigma Chemical Co. (St. Louis, MO) and antibody for smooth muscle actin (CGA7) was from Enzo (New York, NY). All of the other chemicals were purchased from Sigma Chemical Co.

Statistical analysis. Analysis of variance was used to compare the different groups.

\section{RESULTS}

The fibroblastic characteristics of cells were examined to determine if the cells had any smooth muscle-like characteristics. Ultrastructurally, the cells have cytoplasmic lipid vacuoles, a small amount of microfilaments, and prominent cisternae of rough endoplasmic reticulum. Often, collagen fibers were recognized extracellularly. However, none of the cells at $10 \mathrm{~d}$ in culture had an incomplete basal lamina surrounding the plasma membrane as is characteristic of smooth muscle cells (Fig. 1). Immunostaining was positive for vimentin but negative for smooth muscle antigens: smooth muscle actin, smooth muscle myosin, and desmin (Fig. 2). Thus, ultrastructurally and immunohistochemically, the cells were fibroblasts and not differentiated smooth muscle cells. When these cells were treated with IGF-I, concentrations of TE in the cultured media increased in a dose-response manner and were $86 \pm 14 \%$ greater than control at an IGF-I concentration of $500 \mathrm{ng} / \mathrm{mL}$ (Fig. 3). The ${ }^{3} \mathrm{H}$-leucine incorporation increased progressively, and was $35 \pm 5 \%$ greater than control at $500 \mathrm{ng} / \mathrm{mL}$. Because DEX is known to stimulate TE synthesis in RPF (12), the effect of IGF-I plus DEX was studied. At this lower FCS concentration at $0.5 \%$, DEX did not stimulate TE gene expression and did not increase the effects of IGF-I (Figs. 4 and 5). The TE mRNA in RPF also increased 95 $\pm 20 \%$ at an IGF-I concentration of $500 \mathrm{ng} / \mathrm{mL}$ (Fig. 5); the degree of stimulation was similar to the TE protein.

\section{DISCUSSION}

We have demonstrated that IGF-I is stimulatory for TE synthesis in neonatal RPF. The magnitude of stimulation by IGF-I was less than that reported in the vascular smooth muscle cells $(14,15)$. The IGF-I effect was preferential for TE as compared to that for total protein synthesis estimated by ${ }^{3} \mathrm{H}$-leucine incorporation. Our results support the study by Foster et al. (19) on chick lung explant culture model, which showed that IGF stimulates TE synthesis in this system. However, the cell type responsible for the increased synthesis was not identified in that study. The present study confirmed that RPF are at least one of several responsive populations. Although the origin of the RPF is in question, our in situ hybridization studies have confirmed that the elastogenic fibroblasts in the 7-d rat lung are largely parenchymal rather than vascular adventitial or peribronchial (20). The cells examined were ultrastructurally shown to be fibroblastic and not differentiated smooth muscle cells. By immunofluorescence also, smooth muscle specific antigens were not seen in these cells. The common ultrastructural characteristics in all of the cells examined were prominent rough endoplasmic reticulum cisternae and lack of basal lamina around the plasma membranes. Cultured vascular smooth muscle cells change from a contractile to a synthetic phenotype in culture $(21,22)$, which includes development of prominent rough endoplasmic reticulum cisternae (22) and formation of an incomplete basal lamina within a few days. These characteristics distinguish smooth muscle cells from fibroblasts (22). Because cells were in culture for $10 \mathrm{~d}$ before fixation, a basal lamina should have been detected if they were in fact differentiated smooth muscle cells. Thus, the IGF-I effect on TE synthesis is not restricted to vascular smooth muscle cells, and it could possibly stimulate TE in the lung parenchyma in vivo. However, the results should be interpreted with caution because the maximal concentration to elicit a significant response was higher than the usually observed cellular response by IGF (23). The response was not mediated by insulin receptors because insulin stimulation of TE required an approximately 20 times greater molar concentration than IGF-I (unpublished observations). The fact that DEX with $0.5 \%$ FCS alone or in combination with IGF-I did not stimulate TE synthesis in this study contrasts with the results of our previous study using $10 \%$ FCS, when this was achieved (12). This suggests that DEX stimulation of TE requires a higher concentration of other factor(s) different from IGF-I that are present in FCS. 
The physiologic role of IGF in the developmental lung is far from clear, and their specific effects on extracellular matrix formation in the lung are limited. IGF-I was shown to stimulate collagen in human lung fibroblasts in vitro (24). IGF-I is secreted by fetal rat lung fibroblasts and stimulates cell multiplication in an autocrine or paracrine fashion (25). The question of whether IGF-I plays a significant role in lung morphogenesis and/or in the disease states through modulation of extracellular matrices such as elastin and collagen remains to be answered.

Acknowledgment. The authors thank Daphne deMello, M.D., for reviewing the manuscript.

\section{REFERENCES}

1. Amy RWM, Bowes D, Burri PH, Haines J, Thurlbeck WM 1977 Postnatal growth of the mouse lung. J Anat 24:131-15

2. Burri H 1974 The postnatal growth of the rat lung. III. Morphology. Anat Rec 180:77-98

3. Brody J, Vaccaro C 1979 Postnatal formation of alveoli. Interstitial events and physiologic consequences. Fed Proc 38:215-223

4. Loosli CG, Potter EL 1959 Pre and postnatal development of the respiratory portion of the human lung. Am Rev Respir Dis 80:5-20

5. Fukuda Y, Ferrans VJ, Crystal RG 1983 The development of alveolar septa in fetal sheep lung. An ultrastructural and immunohistochemical study. Am J Anat 167:405-439

6. deZabala LE, Weisman D 1984 Prenatal Development of the bovine lung. Zentralbl Veterinarmed [c] 13:1-14

7. Emery JL 1970 The postnatal development of the human lung and its implication for lung pathology. Respiration 27(suppl):41-50

8. Vaccaro C, Brody JS 1978 Ultrastructure of developing alveoli. I. The role of the interstitial fibroblast. Anat Rec 192:467-480

9. Rosenbloom J 1984 Biology of disease. Elastin: relation of protein and gene structure to disease. Lab Invest 51:604-623

10. Campagnone R, Regan J, Rich CB, Miller M, Keene DR, Sakai L, Foster JA 1987 Pulmonary fibroblasts for studying elastin synthesis. Lab Invest 56:224230

11. Fazio MJ, Kahari V-M, Bashir MM, Saitta B, Rosenbloom J, Uitto J 1990 Regulation of elastin gene expression: evidence for functional promoter activity in the 5 -franking region of the human gene. J Invest Dermatol 94:191-196

12. Noguchi A, Firshing K, Kursar JD, Reddy R 1990 Developmental changes of tropoelastin by rat pulmonary fibroblasts and effects of dexamethasone. Pediatr Res 28:379-382

13. Foster, JA, Rich CB, Florini JR 1987 Insulin-like growth factor I, somatomedin $\mathrm{C}$, induces the synthesis of tropoelastin in aortic tissue. Coll Relat Res 7:161169

14. Badesch DB, Lee PDK, Parks WC, Stenmark KR 1989 Insulin-like growth factor I stimulates elastin synthesis by bovine pulmonary arterial smooth muscle cells. Biochem Biophys Res Commun 160:382-387

15. Post M, Barsoumian A, Smith BT 1986 The cellular mechanism of glucocorticoid acceleration of fetal lung maturation. J Biol Chem 261:2179-2184

16. Partridge SM, Davis HF, Adair AS 1955 The chemistry of connective tissues. 2. Soluble proteins derived from partial hydrolysis of elastin. Biochem $\mathrm{J}$ 61:11-21

17. Denhardt DT 1966 A membrane-technique for detection of complimentary DNA. Biochem Biophys Res Commun 23:641-646

18. Cleveland DW, Lopata MA, McDonald RJ, Cowan NJ, Rutter WJ, Kirschner MW 1980 Number and evolutionary conservation of $\alpha$ - and $\beta$-tubulin and cytoplasmic $\beta$-actin and $\tau$-actin genes using specific cloned cDNA probes. Cell 20:95-105

19. Foster JA, Rich CB, Curtiss SW, Regan J 1989 Elastin. In: Massaro DI (ed) Lung Biology in Health and Disease, Vol 41, Lung Cell Biology. Marcel Decker, Inc., New York, pp 867-905

20. Noguchi A, Samaha H 1991 Developmental changes in tropoelastin gene expression in the rat lung studied by in-situ hybridization. Am J Respir Cell Mol Biol (in press)

21. Thyberg J, Plamberg I, Nilsson J, Ksiazek T, Sjolund M 1983 Phenotype modulation in primary cultures of arterial smooth muscle cells. Differentiation 25:156-167

22. Chamley-Campbell J, Campbell GR, Ross R 1979 The smooth muscle cell in culture. Physiol Rev 59:1-61

23. Mcquillan DJ, Handley CJ, Campbell MA, Bolis S, Milway VE, Herington AC 1986 Stimulation of proteoglycan biosynthesis by serum and insulin-like growth factor-I in cultured bovine articular cartilage. Biochem J 240:423430

24. Goldstein RH, Poliks CF, Pilch PF, Smith BD, Fine A 1989 Stimulation of collagen formation by insulin and insulin-like growth factor $\mathrm{I}$ in cultures of human lung fibroblasts. Endocrinology 124:964-970

25. Stiles AD, D'Ercole J 1990 The insulin-like growth factors in the lung. Am J Respir Cell Mol Biol 3:93-100 